\title{
Rubiaceae in Brazilian Atlantic Forest remnants: floristic similarity and implications for conservation
}

\author{
Alessandra Marques de Paiva ${ }^{1}$, Felipe Fajardo Villela Antolin Barberena ${ }^{2} \&$ \\ Rosana Conrado Lopes ${ }^{3 *}$ \\ 1. Programa de Pós-Graduação em Ciências Biológicas (Botânica), Universidade Federal do Rio de Janeiro, Quinta da \\ Boa Vista s.n., São Cristóvão, 20940-040, Rio de Janeiro, RJ, Brasil; alessandrambot@gmail.com \\ 2. Instituto de Pesquisas Jardim Botânico do Rio de Janeiro, Rua Pacheco Leão 915, Jardim Botânico, 22460-030, Rio \\ de Janeiro, RJ, Brasil; lipefajardovab@yahoo.com.br \\ 3. Laboratório Integrado de Sistemática Vegetal, Instituto de Biologia, Universidade Federal do Rio de Janeiro, Professor \\ Rodolpho Paulo Rocco s.n., Prédio do CCS, Bloco A, Sala A1-88, Ilha do Fundão, 21941-490, Rio de Janeiro, RJ, \\ Brasil; rosana@biologia.ufrj.br \\ * Correspondence.
}

$$
\text { Received 05-V-2015. Corrected 16-I-2016. Accepted 16-II-2016. }
$$

\begin{abstract}
Brazil holds most of the Atlantic Forest Domain and is also one of the Rubiaceae diversity centers in the Neotropics. Despite the urban expansion in the state of Rio de Janeiro, large areas of continuous vegetation with high connectivity degree can still be found. Recently, new Rubiaceae species have been described in the Rio de Janeiro flora, which present small populations and very particular distribution. The current paper analyzed the similarity in the floristic composition of the Rubiaceae in eight Atlantic Forest remnants of Rio de Janeiro state protected by Conservation Units. We also surveyed and set guidelines for conservation of microendemic species. The similarity analysis were based on previously published studies in Área de Proteção Ambiental de Grumari, Área de Proteção Ambiental Palmares, Parque Estadual da Serra da Tiririca, Parque Nacional do Itatiaia, Parque Nacional de Jurubatiba, Reserva Biológica de Poço das Antas, Reserva Biológica do Tinguá and Reserva Ecológica de Macaé de Cima - using the PAST software ("Paleontological Statistics") with Sørensen coefficient. The floristic similarity analysis revealed two groups with distinct physiographic characteristics and different vegetation types. Group A consisted in two Restinga areas, Área de Proteção Ambiental de Grumari and Parque Nacional de Jurubatiba, which showed strong bootstrap support (98\%). Group B included forest remnants with distinct phytophisiognomies or altitudes, but with moderate bootstrap support. Low similarity levels among the eight areas were found due to the habitats' heterogeneity. The current study pointed out 19 microendemic species from the Atlantic Forest, they present a single-site distribution or a distribution restricted to Mountain and Metropolitan regions of Rio de Janeiro state. Concerning the conservation status of microendemic species, discrepancies between the Catalogue of Flora of Rio de Janeiro and the Red Book of Brazilian Flora (two of the main reference catalogs of Brazilian flora) have been identified. We have also highlighted the need for recollecting microendemic species from the Atlantic Forest, and for properly assessing the degree of threat faced by these taxons early. Rev. Biol. Trop. 64 (2): 655-665. Epub 2016 June 01.
\end{abstract}

Key words: endangered species, hotspot, microendemism, Restinga, Rio de Janeiro.

Rubiaceae has worldwide distribution and it is the fourth richest family among flowering plants (Robbrecht, 1998; Govaerts, Frodin, Ruhsan, Bridson, \& Davis, 2015). Brazil is one of the Rubiaceae diversity centers in the Neotropics (Delprete \& Jardim, 2012), the country hosts 125 genera and ca. 1400 species, thus totaling $10 \%$ of recognized Rubiaceae species in the world (Barbosa et al., 2015). This family is relatively well represented in all the Brazilian phytogeographic domains. It has wide distribution in the different phytophisiognomies 
and vegetation types of Atlantic Forest, from Ombrophilous Forests to Restingas and Campos Rupestres (Barroso, Peixoto, Ichaso, Costa, \& Guimarães, 1991; Delprete \& Jardim, 2012).

The relevance and representativeness of Rubiaceae in the Atlantic Forest is evidenced in floristic studies through its high richness, abundance and endemism (Lima \& GuedesBruni, 1997; Pessoa, Guedes-Bruni, \& Kurtz, 1997; Kurtz \& Araujo, 2000; Stehman et al., 2009). Many species, especially subshrubs, play a fundamental role in the tropical forest community structures, they are the food source of mammals, birds and insects that feed on pollen, nectar and fruits (Castro \& Oliveira, 2002; Melo, Bento, \& Oliveira, 2003). The genera Psychotria L., Coccocypselum P.Browne, Manettia Mutis ex L. and Spermacoce L. are important to the recovering of degraded Atlantic Forest areas, specially in the early stages of succession, due to the expressive richness of these species (Citadini-Zanette, Delfino, BrumFigueiró, \& Santos, 2009).

Although the Atlantic Forest presents great biological complexity and high richness and endemism levels, it is one of the most threatened phytogeographic domain on the planet (Davis et al., 1986; Mittermeier et al., 2004). It was reduced to ca. $11 \%$ of its original coverage, and presents predominantly small fragments - smaller than 100 ha (Stehmann et al., 2009). The Atlantic Forest areas in the state of Rio de Janeiro have also been continuously reduced, mainly due to the growth of cities (Peixoto, Martins, Silva, \& Silva, 2004). However, there are still large continuous vegetation areas with high connectivity degree in the state (Rocha, Bergallo, Alves, \& van Sluys, 2003). These forest areas are predominantly located in the Montane and High-Montane formations of Rio de Janeiro (above $500 \mathrm{~m}$ ) and almost $50 \%$ of these forests are protected by Conservation Units (Fundação SOS Mata Atlântica / INPE, 2014).

Recently, Rubiaceae flora and floristic surveys were conducted in Restinga and forest areas of the state - complete and partial protection areas (Gomes, 1996, 2001; Barros, 2008;
Lima, 2008; Lima et al., 2008; Silva-Neto \& Peixoto, 2012; Paiva, \& Lopes, 2013; Paiva, \& Lopes, com.pess.). In this context, new Rubiaceae species have been described in the Rio de Janeiro state and they showed localized distributions and small populations (Gomes, 2003a; Silva-Neto \& Ávila, 2007; Jardim \& Zappi, 2008). At the same time, the complex taxonomy of different genera in the Atlantic Forest was checked (Gomes, 2003b).

In consonance with the efforts to compile and provide updated informations about Rio de Janeiro flora (Baumgratz et al., 2014), and take into account the floristic and ecological importance of Rubiaceae in Brazil, the current study aimed to assess the floristic relations in Atlantic Forest remnants -including different types of vegetation- based on Rubiaceae. In addition, we sought to survey and set guidelines for conservation of microendemic species within this phytogeographic domain.

\section{MATERIAL AND METHODS}

Similarities in the composition of Rubiaceae species was evaluated according to surveys conducted in eight Atlantic Forest areas in the State of Rio de Janeiro, Brazil - Área de Proteção Ambiental de Grumari (APA Grumari), Área de Proteção Ambiental Palmares (APA Palmares), Parque Estadual da Serra da Tiririca (PESET), Parque Nacional do Itatiaia (PARNA Itatiaia), Parque Nacional de Jurubatiba (PARNA Jurubatiba), Reserva Biológica de Poço das Antas (REBIO Poço das Antas), Reserva Biológica do Tinguá (REBIO Tinguá) and Reserva Ecológica de Macaé de Cima (RE Macaé de Cima) (Gomes, 1996, 2001; Barros, 2008; Lima, 2008; Lima et al., 2008; SilvaNeto \& Peixoto, 2012; Paiva \& Lopes, 2013; Paiva, \& Lopes, 2015 pers. comm.; Fig. 1). The main physiographic features of these areas are listed in Table 1. The phytogeographic area classification followed Fiaschi and Pirani (2009); the vegetation types were according to Veloso, Rangel Filho and Lima (1991) and the weather was classified as per Koëppen's classification (1948). 


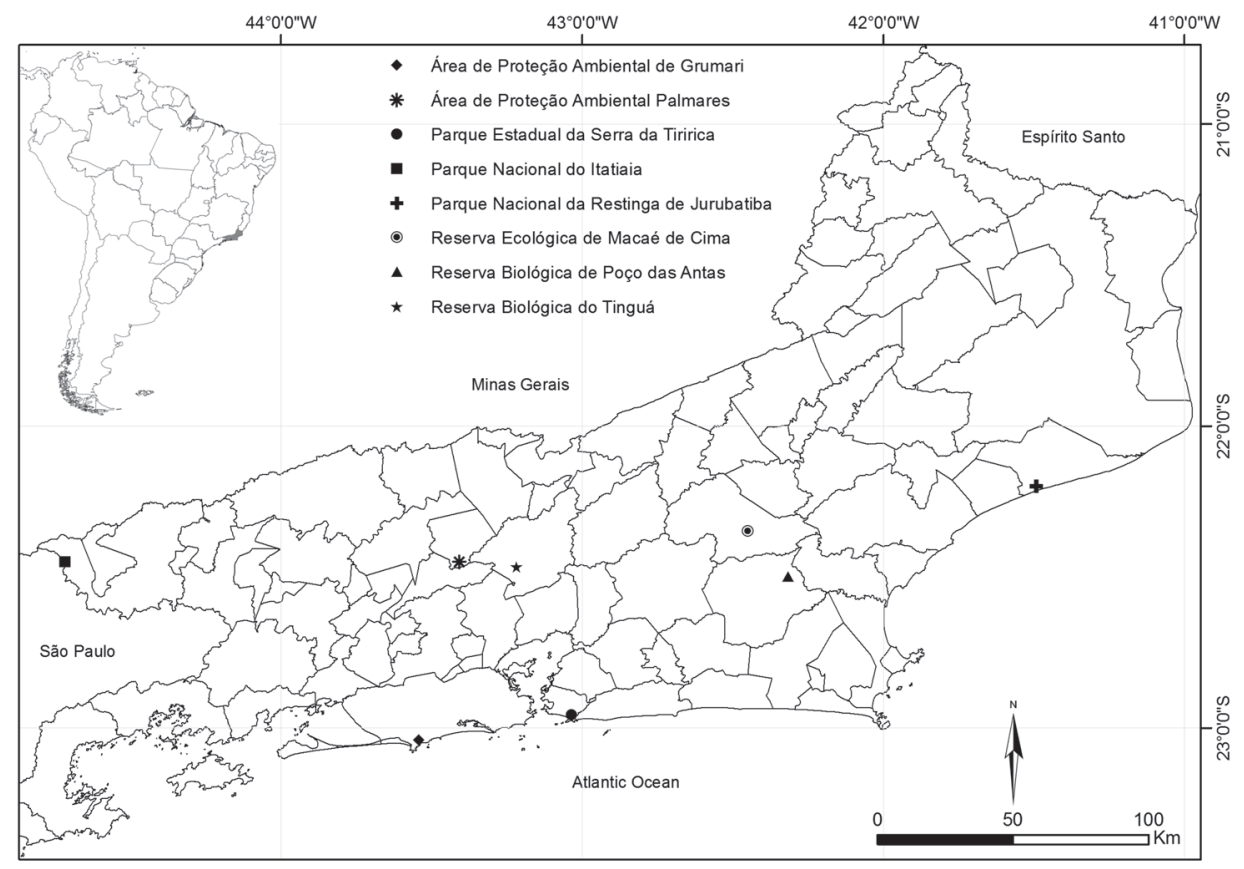

Fig. 1. The eight Atlantic Forest Protected Areas in the State of Rio de Janeiro, Brazil: Área de Proteção Ambiental de Grumari (APA Grumari), Área de Proteção Ambiental Palmares (APA Palmares), Parque Estadual da Serra da Tiririca (PESET), Parque Nacional do Itatiaia (PARNA Itatiaia), Parque Nacional de Jurubatiba (PARNA Jurubatiba), Reserva Biológica de Poço das Antas (REBIO Poço das Antas), Reserva Biológica do Tinguá (REBIO Tinguá) and Reserva Ecológica de Macaé de Cima (RE Macaé de Cima).

TABLE 1

List of Conservation Units used in the similarity analysis

\begin{tabular}{lcccccc}
\multicolumn{1}{c}{ Conservation Unit } & $\mathrm{N}$ & Coordinates & Altitude $(\mathrm{m})$ & Climate & Phytophisiognomy & Reference \\
APA Grumari & 14 & $4^{\circ} 32^{\prime} \mathrm{S}-23^{\circ} 03^{\prime} \mathrm{W}$ & $0-15$ & Aw & RE & Paiva \& Lopes com.pess. \\
APA Palmares & 37 & $22^{\circ} 28^{\prime} \mathrm{S}-43^{\circ} 26^{\prime} \mathrm{W}$ & $676-1.216$ & $\mathrm{Aw}$ & MODF & Paiva \& Lopes (2013) \\
PESET & 47 & $2^{\circ} 00^{\prime} \mathrm{S}-43^{\circ} 02^{\prime} \mathrm{W}$ & $120-412$ & $\mathrm{Aw}$ & SODF & Barros (2008) \\
PARNA Itatiaia & 48 & $2^{\circ} 33^{\prime} \mathrm{S}-44^{\circ} 45^{\prime} \mathrm{W}$ & $540-2.791$ & $\mathrm{Cwb}, \mathrm{Cpb}$ & AC, HMODF, MODF & Silva-Neto \& Peixoto (2012) \\
PARNA Jurubatiba & 27 & $2^{\circ} 12^{\prime} \mathrm{S}-41^{\circ} 29^{\prime} \mathrm{W}$ & $0-12$ & $\mathrm{Cfb}$ & $\mathrm{RE}$ & Gomes (2001) \\
Rebio Poço das Antas & 29 & $22^{\circ} 33^{\prime} \mathrm{S}-42^{\circ} 19^{\prime} \mathrm{W}$ & $30-60$ & $\mathrm{Am}$ & LF & Lima et al. (2008) \\
Rebio do Tinguá & 35 & $22^{\circ} 39^{\prime} \mathrm{S}-43^{\circ} 34^{\prime} \mathrm{W}$ & $500-1.600$ & $\mathrm{Am}$ & MODF & Lima (2008) \\
RE Macaé de Cima & 47 & $22^{\circ} 28^{\prime} \mathrm{S}-42^{\circ} 35^{\prime} \mathrm{W}$ & $880-1.719$ & $\mathrm{Cfb}$ & AC, HMODF, MODF & Gomes (1996)
\end{tabular}

$\mathrm{N}=$ number of Rubiaceae species. Conservation Unit: APA Grumari = Área de Proteção Ambiental de Grumari, APA Palmares $=$ Área de Proteção Ambiental Palmares, PESET $=$ Parque Estadual da Serra da Tiririca, PARNA Itatiaia $=$ Parque Nacional do Itatiaia, PARNA Jurubatiba = Parque Nacional de Jurubatiba, REBIO Poço das Antas = Reserva Biológica de Poço das Antas, REBIO Tinguá = Reserva Biológica do Tinguá, RE Macaé de Cima = Reserva Ecológica de Macaé de Cima. Phytophisiognomy: $\mathrm{AC}=$ Altitude Field, HMODF $=$ High Montane Ombrophilous Dense Forest, LF $=$ Lowland Forest, $\mathrm{MODF}=$ Montane Ombrophilous Dense Forest, $\mathrm{RE}=$ Restinga, SODF $=$ Submontane Ombrophilous Dense Forest. 
The List of Flora Species in Brazil and the Catalog Plant of the State of Rio de Janeiro (Barbosa et al., 2014, 2015) are two of the main references on flora catalogs and they were used to assess synonyms and to confirm the occurrence of the species in Rio de Janeiro. Species not included in these databases were considered erroneous identifications and were then excluded from the analysis. Taxa without precise identification to species level were excluded as well.

We developed a species presence and absence matrix for all eight areas. The flora similarity analysis was performed using the PAST software ("Paleontological Statistics"). We used the coefficient of Sorensen because this similarity index gives greater importance to the shared species than to those that belong to a single area, thus allowed to highlight some groups (Hammer, Harper, \& Ryan, 2001). Similarity values below 0.5 were considered low (Kent \& Coker, 1992). We developed a dendrogram (Fig. 2) based on the non-weighted average algorithm method (UPGMA) only for the clusters that could be seen. A total of 5000 bootstrap replicates were used to calculate the internal support of the clusters. Based on Andersson and Rova (1999) we adopted the following bootstrap categories: strong (81-100 $\%)$, moderate $(51-80 \%)$, and weak $(<50 \%)$ (the "weak" category reflect lack of support).

Information concerning the geographical distribution of Rubiaceae species followed that by Barbosa et al. (2014, 2015), and microendemic species from the Atlantic Forest were marked in the present study. The conservation status for those species was obtained in Zappi et al. (2013). CRIA database (2015) was consulted to provide the number of specimens per species deposited in the herbaria by species. Rio de Janeiro regional division was found in CEPERJ (2015).

\section{RESULTS}

The analysis showed low floristic similarity among the eight areas concerning the Rubiaceae species (Fig. 2). The dendrogram showed the formation of two groups. Group A consisted of APA Grumari and PARNA Jurubatiba, it presented similarity of 0.48 and strong

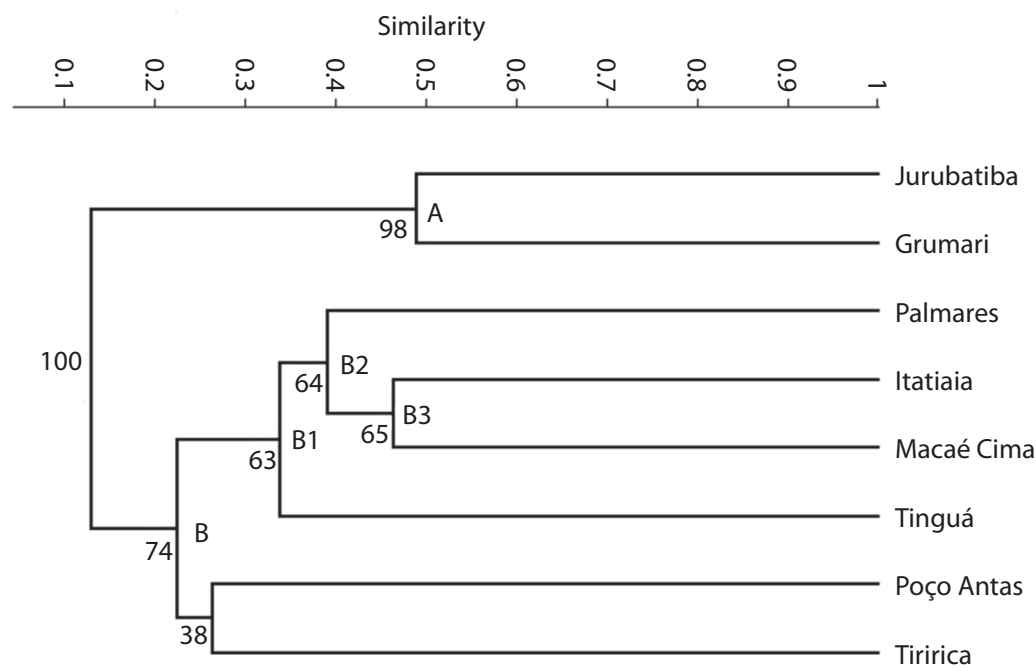

Fig. 2. Rubiaceae floristic similarities in the eight Brazilian Atlantic Forest remnants according to the Sørensen's index and the UPGMA algorithm, with 5000 bootstrap replications. Cophenetic Correlation Coefficient $=0.9072$. Grumari $=$ Área de Proteção Ambiental de Grumari, Itatiaia = Parque Nacional do Itatiaia, Jurubatiba = Parque Nacional de Jurubatiba, Macaé de Cima = Reserva Ecológica de Macaé de Cima, Palmares = Área de Proteção Ambiental Palmares, Poço Antas = Reserva Biológica de Poço das Antas, Tinguá = Reserva Biológica de Tinguá, Tiririca = Parque Estadual da Serra da Tiririca. 
bootstrap support (98\%). Group B included APA Palmares, PARNA Itatiaia, PESET, RE Macaé de Cima, REBIO Poço das Antas and REBIO Tinguá, with $74 \%$ bootstrap support. Inside this large group, we identified three subgroups with moderate support (63-65\%) (Fig. 2). APA Palmares, PARNA Itatiaia, RE Macaé de Cima and REBIO Tinguá formed the subgroup B1, the first three areas formed the subgroup B2, whereas PARNA Itatiaia and RE Macaé de Cima showed the highest similarity (0.46) in group B, and formed the subgroup B3.

By contrast, Poço das Antas and PESET presented weak bootstrap support (38\%) (Fig. 2).

The Rubiaceae species presence and absence matrix developed for the eight areas consisted of 44 genera and 159 species, all the species that could be found in the areas. However, more than $60 \%$ of these species were restricted to a single area. The highest number of species found in a single location was: PESET, 22 species; PARNA Itatiaia, 16 species; RE Macaé de Cima, only 14; REBIO Tinguá, 12; PARNA Jurubatiba, 11; Poço das Antas, 10; and only one species in APA Grumari and APA Palmares (supplementary material).

Ca. $12 \%$ (19 species) of the species considered in the current study are endemic to the Atlantic Forest and restricted to the state of Rio de Janeiro. Chomelia estrelana Müll. Arg., Coussarea friburgensis $\mathrm{M}$. Gomes, C. speciosa K. Schum. ex M. Gomes, C. strigosipes Müll. Arg., Faramea filamentosa Müll. Arg., F. urophylla Müll. Arg., Psychotria brachyanthema Standl., P. caudata M. Gomes, P. subspathacea Müll. Arg., P. tenuinervis Müll. Arg., P. ulei Standl., Randia itatiaiae S.J. Silva Neto \& R. Ávila, Rudgea discolor Benth., R. insignis Müll. Arg., Rustia gracilis K. Schum are exclusively found in the Ombrophilous Dense Forest. Faramea intercedens Müll. Arg. grows only in Restinga, while Faramea calyciflora A. Rich. ex DC. and Manettia fimbriata Cham. \& Schltdl. are found in both areas. Hindsia glabra $\mathrm{K}$. Schum. is endemic of the Altitude Fields of PARNA Itatiaia.
The highest number of evaluated microendemic species are found in RE Macaé de Cima (ten species), five in PESET, four in PARNA Itatiaia, three in REBIO Tinguá, and only one is found in PARNA Jurubatiba and APA Grumari. The microendemic species from the Atlantic Forest presented a single-site distribution, like Hindsia glabra, or a distribution restricted to a few cities mainly located in Mountain and Metropolitan regions of the state (e.g. Rudgea insignis; Table 2).

\section{DISCUSSION}

The floristic similarity analysis revealed two groups with distinct physiographic characteristics and different vegetation types. Group A (APA Grumari and PARNA Jurubatiba) consisted in two Restingas areas bathed by the Atlantic Ocean and placed ca. $300 \mathrm{~km}$ far from each other. Despite the distance, APA Grumari and PARNA Jurubatiba presented floristic similarity with strong bootstrap support (98\%). This result corroborated data presented by De Abreu, Menini Neto and Konno (2011), who noticed lack of correlation between floristic similarity and geographic distance. Recently, Moreira, Barberena and Lopes (2014) suggested temperature, precipitation and the proximity to the Atlantic Forest as key environmental factors in the occurrence of species in Restinga areas. According to Argôlo (2001) and Araujo et al. (1998), APA Grumari and PARNA Jurubatiba have the same climate, tropical type - hot and rainy summer and sub-dry winter. The annual mean temperature and precipitation respectively correspond to $23.7^{\circ} \mathrm{C}$ and 901.1 $\mathrm{mm}$ in APA Grumari (Argôlo, 2001), and in PARNA Jurubatiba they correspond to $23.6{ }^{\circ} \mathrm{C}$ and $1.027 \mathrm{~mm}$ (Araujo et al., 1998). Therefore, it is possible stating that these areas' species suffer similar influences from physical factors; particularly from temperature and precipitation. The floristic similarity can also be explained by the lower habitat heterogeneity in sandbanks when it was compared to that in forest formations. Adverse weather conditions such as high temperature and salinity influence 
TABLE 2

Microendemic Rubiaceae species found in Atlantic Forest remnants in the state of Rio de Janeiro, Brazil, it highlights the vegetation types, Conservation Units (CUs) and occurrence regions in the state

\begin{tabular}{lccc}
\multicolumn{1}{c}{ Species } & Vegetation types & CUs & Regions \\
Chomelia estrelana & OF & REBIO Tinguá, RE Macaé de Cima & ME, MR \\
Coussarea friburgensis & OF & RE Macaé de Cima & MR \\
Coussarea speciosa & OF & RE Macaé de Cima & MR \\
Coussarea strigosipes & OF & PARNA Itatiaia & MP \\
Faramea calyciflora & OF, RE & PESET & ME \\
Faramea filamentosa & OF & REBIO Tinguá & ME \\
Faramea intercedens & RE & RE Macaé de Cima & MR \\
Faramea urophylla & OF & RE Macaé de Cima & MR \\
Hindsia glabra & AC & PARNA Itatiaia & MP \\
Manettia fimbriata & OF, RE & RE Macaé de Cima, & ME, MR \\
(= Manettia mitis var. fimbriata $)$ & & PESET, APA Grumari & MR \\
Psychotria brachyanthema & OF & RE Macaé de Cima & MR \\
Psychotria caudata & OF & RE Macaé de Cima & ME \\
Psychotria subspathacea & OF & PESET & MR \\
Psychotria ulei & OF & RE Macaé de Cima & MP \\
Randia itatiaiae & OF & PARNA Itatiaia & ME \\
Rudgea discolor & OF & OF & PESET \\
Rustia gracilis & OF & PARNA Itatiaia, RE Macaé de Cima & MP, MR \\
\hline
\end{tabular}

Conservation Units: APA Grumari = Área de Proteção Ambiental de Grumari, PESET = Parque Estadual da Serra da Tiririca, PARNA Itatiaia $=$ Parque Nacional do Itatiaia, PARNA Jurubatiba $=$ Parque Nacional de Jurubatiba, REBIO Tinguá $=$ Reserva Biológica do Tinguá, RE Macaé de Cima = Reserva Ecológica de Macaé de Cima. Vegetation types: AC = Altitude Field, $\mathrm{OF}=$ Ombrophilous Forest, $\mathrm{RE}=$ Restinga. Regions: $\mathrm{ME}=$ Metropolitan, $\mathrm{MP}=$ Middle Paraíba, $\mathrm{MR}=\mathrm{Mountain}$ region.

the establishment of more Rubiaceae species and it may possibly explain the low number of species found in these two protected areas.

Group B consisted in six forest remnants that differ in phytophisiognomy or altitude. Subgroup B1 comprised APA Palmares, PARNA Itatiaia, RE Macaé de Cima and REBIO Tinguá. All these legally protected areas include remnants of the Montane Ombrophilous Dense Forest. However, APA Palmares and REBIO Tinguá present lower altitudinal variation. The altitudinal dimensions range from 676 to $1216 \mathrm{~m}$ in APA Palmares, and it is broader in REBIO Tinguá -500-1 $600 \mathrm{~m}$-, thus also covering stretches of High Montane Dense Forest. PARNA Itatiaia and RE Macaé de Cima form the subgroup B3, possibly due to the heterogeneity of most habitats, because they cover large areas of High Montane and Altitude Field formations. In contrast, PESET covers Submontane formations (120-412 m) and Poço das Antas comprises lowland forests (30-60 m). Their different vegetation formations and narrow altitudinal range, when they are compared to those of other group B sites, can explain the segregation of other Consevation Units and also the lack of bootstrap support between PESET and Poço das Antas. The low floristic similarity indicates that the species from the Atlantic Forest are spatially distributed in mosaics and they are favored by the habitats heterogeneity; the communities are floristically and structurally different. Such information corroborates previous studies that have reported high diversity of tropical area flora (Campbell \& Hammond, 1989; Thomas, 1999). 
The state of Rio de Janeiro is located between two of the four Atlantic Forest endemism hotspot centers: Rio Doce region, in the State of Espírito Santo and the North of São Paulo State (Aguiar, Chiarello, Mendes, \& Matos, 2005; Murray-Smith et al., 2009). It is also known that the state presents high concentrations of animal and plant endemic species (Rocha et al., 2004; Baumgratz et al., 2014). Thus, the restricted geographical distribution pattern shown by the 19 species is not unexpected and can be primarily explained by two hypotheses. First, the Atlantic Forest is a unique ecosystem, with geographic and climatic variables that include different geographical barriers as well as extensive latitudinal, longitudinal and altitudinal ranges (from sea level to $2890 \mathrm{~m}$ ) and regional differences in rainfall, thus favoring speciation and biodiversity (Oliveira-Filho \& Fontes, 2000; Câmara, 2005; Silva \& Casteleti, 2005; Siqueira-Filho \& Leme, 2006). The distribution of $H$. glabra and $R$. insignis can be explained by restrictive and particular environmental conditions. Hindsia glabra occurs only at High Altitude fields (Silva-Neto \& Peixoto, 2012), wherein altitude and probably high luminosity are limiting factors, whereas $R$. insignis is restricted to Montane Dense Ombrophilous Forest fragments (Barbosa et al., 2014); both species are also subjected to some threats, like fire and land speculation.

Second, microendemic species have recent speciation and have not dispersed to other areas (Costa, Trovó, \& Sano, 2008). Randia itatiaiae presents a single-site distribution and it is morphologically closer to Randia armata (Sw.) DC., an species widely distributed in Rio de Janeiro state, including in Itatiaia (SilvaNeto \& Ávila, 2007; Barbosa et al., 2014). Although, Silva-Neto and Ávila (2007) have pointed out that there is no sympatry evidence between the species to date, the recent speciation is a hypothesis. Therefore, environmental heterogeneity is a promising field for studies and it is substantially important to the analysis and understanding of distribution patterns and barriers that limit the species, including the other Rubiaceae microendemic species. Studies on reproductive biology, phylogeny and biogeography of these species are also considered relevant to the understanding of distribution patterns (Stehmann et al., 2009).

The occurrence of Atlantic Forest microendemic species in all the herein listed protected areas allows us to highlight the importance of these forest ecosystems - particularly the mountainous and coastal strip areas of Rio de Janeiro State - for the preservation of Rubiaceae. The main strategies adopted for flora conservation are the establishment, maintenance and expansion of protected areas to primarily protect endemic and endangered species (Heywood \& Iriondo, 2003). However, as soon as the protected areas are set, the establishment of ecological corridors and the improvement of quality matrices are the complementary alternatives to preserve flora richness (Ayres et al., 2005). Moreover, as financial resources for biodiversity conservation are limited and dependent on the economy, the selection of groups of species and priority areas for conservation is essencial (Vane-Wright, Humphries, \& Williams, 1991; Loyola, Kubota, \& Lewinsohn, 2007; Loyola, \& Lewinsohn, 2009). In this context, the expressive richness of microendemic species in RE Macaé de Cima (ten spp.), including Rudgea insignis, a threatened species, allows highlighting it as a forest getaway for this family. Therefore, RE Macaé de Cima is a prior protected area for research and financial resource investments, associated with action plans and management strategies regarding Rubiaceae.

With regards to microendemic species conservation status, data presented by Barbosa et al. (2014) in the Flora Catalog of Rio de Janeiro State do not meet those available by Zappi et al. (2013) in the Red Book of Brazil Flora. Barbosa et al. (2014) considered Hindsia glabra and Rudgea insignis respectively as Critically Endangered and Endangered. Zappi et al. (2013) classified these species respectively as Endangered and Vulnerable. It somehow derives from the absence of the explicit used criteria and from the lack of consensus 
and debate among botanists who work with the family. Although only Rudgea insignis and Hindsia glabra are officially listed as under extinction threat, other species should be evaluated and probably thicken the list. It happens because many of these species present restricted distribution in the state of Rio de Janeiro, and are found in just one phytophysiognomy or, exclusively, in protected areas; they can also have low population density. All these aspects are criteria taken under consideration when the list of endangered species is set, especially when these conditions occurs together (Souza et al., 2007). However, Zappi et al. (2013) [according to Martinelli et al., 2013] evaluated 111 Myrtaceae species and it corresponds to less than $8 \%$ of the species found in Brazil. Therefore, it is very likely that most micro endemic species have not been evaluated, and this is a necessary next step.

Notwithstanding, some species are still represented by very few specimens in herbaria collections, like Faramea intercedens and Rudgea discolor, whereas other species, eg. Randia itatiaiae, have been currently described. It is worth noticing that the conduction of floras and floristic Rubiaceae inventories first took place in protected areas. Thus, so that the degree of threat faced by these taxa may be appropriately evaluated early, we also highlight the need for recollecting microendemic species from the Atlantic Forest. We suggest that these species must be investigated not only in areas of proven occurrence, but also in potentially favorable areas, buffer zones of protected areas and even in sharpest human inteventions areas. We indicate priority formations of Dense Ombrophilous Forests, such as in the Southern of the state.

Finally, we state that the Research Support programs, institutions and research centers, especially those besieged in the state of Rio de Janeiro, must reinforce and encourage research projects that prioritize phylogeographic approaches, and the conservation biology to faster broadcast information about restricted distribution species.

\section{ACKNOWLEDGMENTS}

We are grateful to CAPES and CNPq for the scholarships.

\section{RESUMEN}

Rubiaceae en remanentes de Bosque Atlántico de Brasil: similitud florística e implicaciones para la conservación. Brasil tiene la mayor parte de bosque del Atlántico y también es uno de los centros de diversidad de Rubiaceas del Neotrópico. A pesar de la expansión urbana en el estado de Río de Janeiro, todavía se pueden encontrar grandes áreas de vegetación con alto grado de conectividad. Recientemente, nuevas especies de Rubiaceae se han descrito en la flora de Río de Janeiro, las cuales presentan poblaciones pequeñas y distribuciones particulares. El presente documento analiza la similitud en la composición florística de Rubiaceae en ocho remanentes del bosque Atlántico del estado de Río de Janeiro, protegidos por las Unidades de Conservación. También se inspeccionaron y establecieron directrices para la conservación de especies microendémicas. El análisis de similitud se basó en estudios publicados anteriormente en el área de Protección Ambiental de Grumari, área de Protección Ambiental Palmares, Parque Estatal de Serra da Tiririca, Parque Nacional de Itatiaia, Parque Nacional de Jurubatiba, Reserva Biológica de Poço das Antas, Reserva Biológica de Tinguá y Reserva Ecológica de Macaé de Cima, utilizando el software PAST ("Paleontological Statistics") con coeficiente de Sørensen. El análisis de similitud florística reveló dos grupos con características fisiográficas distintas y diferentes tipos de vegetación. El Grupo A consistió en dos áreas, Área de Protección Ambiental de Grumari y el Parque Nacional de Jurubatiba, que mostraron un fuerte bootstrap support (98\%). El Grupo B incluye remanentes de bosque con fitofisionomía o altitudes distintas, pero con moderado bootstrap support. Los bajos niveles de similitud entre las ocho áreas fueron encontrados debido a la heterogeneidad de los hábitats. El estudio señaló que 19 especies microendémicas del Atlántico presentan una distribución de un solo sitio o una distribución restringida a las regiones de montaña y regiones metropolitanas del estado de Río de Janeiro. En cuanto al estado de conservación de especies microendémicas, se han identificado discrepancias entre el Catálogo de la Flora de Río de Janeiro y el Libro Rojo de la Flora de Brasil (dos de los principales catálogos de referencias de la flora brasileña). También se puso de relieve la necesidad de recolectar especies microendémicas del bosque Atlántico para evaluar temprano y adecuadamente el grado de amenaza que enfrentan estos taxones.

Palabras clave: puntos calientes, microendémicas, Restinga, Río de Janeiro, especies en peligro. 


\section{REFERENCES}

Aguiar, A. P., Chiarello, A. G., Mendes, S. L., \& Matos, E. N. (2005). Os Corredores Central e da Serra do Mar na Mata Atlântica brasileira. In C. Galindo-Leal \& I. G. Câmara (Eds.), Mata Atlântica: biodiversidade, ameaças e perspectivas (pp. 119-132). Belo Horizonte: Fundação SOS Mata Atlântica Conservação Internacional.

Andersson, L., \& Rova, J. H. E. (1999). The rps 16 intron and the phylogeny of the Rubioideae (Rubiaceae). Plant Systematics and Evolution, 214, 161-186.

Araujo, D. S. D., Scarano, F. R., Sá, C. F. C., Kurtz, B. C., Zaluar, H. L. T., Montezuma, R. C. M., \& Oliveira, R. C. (1998). Comunidades Vegetais do Parque Nacional da Restinga de Jurubatiba. In F. A. Esteves (Ed.), Ecologia das lagoas costeiras do Parque Nacional da Restinga de Jurubatiba e do Município de Macaé (pp. 39-62). Rio de Janeiro: Universidade Federal do Rio de Janeiro.

Argôlo, A. M. (2001). Levantamento florístico, caracterização fisionômica e comparação da Restinga de Grumari, RJ, com outras restingas do Estado do Rio de Janeiro (Dissertação de Mestrado). Universidade Federal do Rio de Janeiro, Rio de Janeiro, Brasil.

Ayres, J. M., Fonseca, G. A. B., Rylands, A. B., Queiroz, H. L., Pinto, L. P., Masterson, D., \& Cavalcanti, R. B. (2005). Os corredores ecológicos das florestas tropicais do Brasil. Belém: Sociedade Civil Mamirauá.

Barbosa, M. R. V., Gomes, M., Pereira, M. S., Pessoa, M. C. R., Di Maio, F. R., \& Jardim, J. (2014). Rubiaceae. In J. F. A. Baumgratz, M. A. N. Coelho, A. L. Peixoto, C. M. Mynssen, B. E. H. Bediaga, D. P. Costa, E. Dalcin, E. F. Guimarães, G. Martinell, D. S. P. Silva, L. S. Sylvestre, M. F. Freitas, M. P. Morim, \& R. C. Forzza (Eds.), Catálogo das espécies de plantas vasculares e briófitas do Estado do Rio de Janeiro. Rio de Janeiro, Brasil: Instituto de Pesquisas Jardim Botânico do Rio de Janeiro. Retrieved from http:// florariojaneiro.jbrj.gov.br/.

Barbosa, M. R., Taylor, C., Cabral, E., Jardim, J. G., Pereira, M. S., Calió, M. F., ... Zappi, D. (2015). Rubiaceae. In R. C. Forzza et al. (Eds.), Lista de Espécies da Flora do Brasil. Rio de Janeiro: Instituto de Pesquisas Jardim Botânico do Rio de Janeiro. Retrieved from http://floradobrasil.jbrj.gov.br/jabot/ floradobrasil/FB210/.

Barros, A. A. M. (2008). Análise Florística e Estrutural do Parque Estadual da Serra da Tiririca, Niterói e Maricá, RJ, Brasil (Tese de Doutorado). Escola Nacional de Botânica Tropical, Rio de Janeiro, Brasil.

Barroso, G. M., Peixoto, A. L., Ichaso, C. L. F., Costa, C. G., \& Guimarães, E. F. (1991). Rubiáceas. In Barroso, G. M. (Ed.), Sistemática de angiospermas do Brasil, 3 (pp. 189-228). Viçosa: Imprensa Universitária de Viçosa.
Baumgratz, J. F. A., Coelho, M. A. N., Peixoto, A. L., Mynssen, C. M., Bediaga, B. E. H., Costa, D. P., ... Forzza, R. C. (2014). Catálogo das Espécies de Plantas Vasculares e Briófitas do Estado do Rio de Janeiro. Rio de Janeiro: Instituto de Pesquisas Jardim Botânico do Rio de Janeiro. Retrieved from http:// florariojaneiro.jbrj.gov.br/

Câmara, I. G. (2005). Breve história da conservação da Mata Atlântica. In C. Galindo-Leal \& I. G. Câmara (Eds.), Mata Atlântica: biodiversidade, ameaças e perspectivas (pp. 31-42). Belo Horizonte: Fundação SOS Mata Atântica Conservação Internacional.

Campbell, D. G., \& Hammond, H. D. (1989). Floristic Inventory of Tropical Countries. New York Botanical Garden, 1, 545.

Castro, C. C., \& Oliveira, P. E. (2002). Pollination biology of distilous Rubiaceae in the Atlantic Rain Forest, SE, Brazil. PlantBiology, 4, 640-646.

CEPERJ-Fundação Centro Estadual de Estatísticas, Pesquisas e Formação de Servidores Públicos do Rio de Janeiro. (2015). Estado do Rio de Janeiro, regiões de Governo. Retrieved from http://www.ceperj.rj.gov.br/

Citadini-Zanette, V., Delfino, R. F., Brum-Figueiró, A. C., \& Santos, R. (2009). Rubiaceae na recuperação ambiental no sul de Santa Catarina. Revista de estudos ambientais, 11, 71-82.

Costa, F. N., Trovó, M., \& Sano, P. T. (2008). Eriocaulaceae na Cadeia do Espinhaço: riqueza, endemismos e ameaças. Megadiversidade, 4, 89-97.

CRIA (Centro de Referência em Informação Ambiental). (2015). Specieslink. Retrieved from http://www.cria. org.br.

Davis, S. D., Droop, S. J. M., Gregerson, P., Henson, L., Leon, C. J., Villa-Lobos, J. L., ... Zantovska, J. (1986). Plants in danger. What do we know? Cambridge, UK: International Union for Conservation of Nature and Natural Resources.

De Abreu, N. L., Menini Neto, L., \& Konno, T. U. P. (2011). Orchidaceae das Serras Negra e do Funil, Rio Preto, Minas Gerais, e similaridade florística entre formações campestres e florestais do Brasil. Acta Botanica Brasilica, 25(1), 58-70.

Delprete, P. G., \& Jardim, J. G. (2012). Systematics, taxonomy and floristics of Brazilian Rubiaceae: an overview about the current status and future challenges. Rodriguésia, 63(1), 101-128.

Fiaschi, P., \& Pirani, J. R. (2009). Review of plant biogeographic studies in Brazil. Journal of Systematic and Evolution, 47(5), 477-496.

Fundação SOS Mata Atlântica/INPE. (2014). Atlas dos remanescentes florestais do Rio de Janeiro. Retrieved from: http://www.sosma.org.br/ 
Gomes, M. (1996). Rubiaceae. In M. P. M. Lima \& R. R. Guedes-Bruni (Eds.), Reserva ecológica de Macaé de Cima, Nova Friburgo-RJ: Aspectos Florísticos das espécies vasculares, 2 (pp. 345-426). Rio de Janeiro, Brasil: Instituto de Pesquisas Jardim Botânico do Rio de Janeiro.

Gomes, M. (2001). Rubiaceae. In A. F., Costa \& I. C. A., Dias (Eds.), Flora do Parque Nacional da Restinga de Jurubatiba e arredores, Rio de Janeiro, Brasil: listagem, florística e fitogeografia (pp. 120-124). Rio de Janeiro: Museu Nacional.

Gomes, M. (2003a). Novas espécies de Coussarea Aubl. e Faramea Aubl. (Rubiaceae, tribo Coussareae). Acta Botanica Brasilica, 17, 439-448.

Gomes, M. (2003b). Reavaliação taxonômica de algumas espécies dos gêneros Coussarea Aubl. e Faramea Aubl. (Rubiaceae, tribo Coussareae). Acta Botanica Brasilica, 17, 449-466.

Govaerts, R., Frodin, D. G., Ruhsam, M., Bridson, D. M., \& Davis, A. P. (2015). World Checklist of Rubiaceae. Retrieved from http://apps.kew.org/wcsp/

Hammer, O., Harper, D. A. T., \& Ryan, P. D. (2001). PAST: paleontological statistics software package for education and data analysis. Paleontologia Electronica, $4,1-9$.

Heywood, V. H., \& Iriondo, J. M. (2003). Plant conservation: old problems, new perspectives. Biological Conservation, 113, 321-335.

Jardim, J. G., \& Zappi, D. C. (2008). Two New Species of Faramea (Rubiaceae, Coussareeae) from Eastern Brazil. Novon, 18, 67-71.

Kent, M., \& Coker, P. (1992). Vegetation description analysis. London: Belhaven Press.

Koëppen, W. (1948). Climatologia: con un estudio de los climas de la tierra. México: Fondo de Cultura Económica.

Kurtz, B. C., \& Araujo, D. S. D. de. (2000). Composição florística e estrutura do componente arbóreo de um trecho de Floresta Atlântica na Estação Ecológica Estadual do Paraíso, Cachoeiras de Macacu, Rio de Janeiro, Brasil. Rodriguésia, 51(78/115), 69-112.

Lima, H. C., \& Guedes-Bruni, R. R. (1997). Diversidade de plantas vasculares na Reserva Ecológica de Macaé de Cima. In H. C. Lima \& R. R. Guedes-Bruni (Eds.), Serra de Macaé de Cima: Diversidade, florística e conservação em Mata Atlântica (pp. 29-39). Rio de Janeiro: Instituto de Pesquisas Jardim Botânico do Rio de Janeiro.

Lima, H. C. (2008). Reserva Biológica do Tinguá. Lista de espécies vasculares. Retrieved from http//jbrj.gov.br/ pesquisa/reservatingua/listaespecies/
Lima, H. C., Morim, M. P., Guedes-Bruni, R. R., Sylvestre, L. S., Pessoa, S. V. A., Silva Neto, S. V. A., ... Mansano, V. (2008). Reserva Biológica de Poço das Antas. Lista de espécies vasculares. Retrieved from http://www.jbrj.gov.br/pesquisa/pma/macaedecima/ checklist/Lista_Plantas_Vasculares.htm/

Loyola, R. D., Kubota, U., \& Lewinsohn, T. M. (2007). Endemic vertebrates are the most effective surrogates for identifying conservation priorities among Brazilian ecoregions. Diversity and Distributions, 13, 389-396.

Loyola, R. D., \& Lewinsohn, T. M. (2009). Diferentes abordagens para a seleção de prioridades de conservação em um contexto macrogeográfico. Megadiversidade, 5(1/2), 27-42.

Martinelli, G., Valente, A. S. M., Maurenza, D., Kutschenko, D. C., Judice, D. M., Silva, D. S., ... Penedo, T. S. A. (2013). Avaliações de risco de extinção de espécies da flora brasileira. In G. Martinelli \& M. A. Moraes (Eds.), Livro Vermelho da Flora do Brasil (pp. 60-103). Rio de Janeiro: Instituto de Pesquisas Jardim Botânico do Rio de Janeiro, Rio de Janeiro.

Melo, C., Bento, E. C., \& Oliveira, P. E. (2003). Frugivory and dispersal of Farameacyanea (Rubiaceae) in Cerrado woody plant formations. Brazilian Journal of Biology, 63, 75-82.

Mittermeier, R. A., Gil, P. R., Hoffmann, M., Pilgrim, J., Brooks, T., Mittermeier, C. G., ... Fonseca, G. A. B. (2004). Hotspots Revisited: Earth's biologically richest and most endangered terrestrial ecoregions. Cidade do México: CEMEX \& Agrupacion Sierra Madre.

Moreira, M. M., Barberena, F. F. V. A., \& Lopes, R. C. (2014). Orchidaceae of the Grumari restinga: floristic and similarity among restingas in Rio de Janeiro state, Brazil. Acta Botanica Brasilica, 28(3), 321-326.

Murray-Smith, C., Brummitt, N. A., Oliveira-Filho, A. T., Bachman, S., Moat, J., Lughadha, E. M. N., \& Lucas, E. J. (2009). Plant diversity hotspots in the Atlantical Coastal Forests of Brazil. Conservation Biology, 23(1), 151-163.

Oliveira-Filho, A. T., \& Fontes, M. A. L. (2000). Patterns of floristic differentiation among Atlantic forests in Southeastern Brazil and the influence of climate. Biotropica, 32, 793-810.

Paiva, A. M., \& Lopes, R. C. (2013). Rubiaceae na Área de Proteção Ambiental Palmares, Paty do Alferes, Rio de Janeiro, Brasil. Pesquisas, Botânica, 64, 39-64.

Peixoto, G. L., Martins, S. V., Silva, A. F., \& Silva, E. (2004). Composição florística do componente arbóreo de um trecho de Floresta Atlântica na Área de Proteção Ambiental da Serra da Capoeira Grande, Rio de Janeiro, RJ, Brasil. Acta Botanica Brasilica, 18(1), 151-160. 
Pessoa, S. V. A., Guedes-Bruni, R. R., \& Kurtz, B. C. (1997). Composição florística e estrutura do componente arbustivo-arbóreo de um trecho secundário de floresta montana na Reserva Ecológica de Macaé de Cima. In H. C. Lima \& R. R. Guedes-Bruni (Eds.), Serra de Macaé de Cima: Diversidade, florística e conservação em Mata Atlântica (pp. 147-167). Rio de Janeiro: Instituto de Pesquisas Jardim Botânico do Rio de Janeiro.

Robbrecht, E. (1988). Tropical woody Rubiaceae. Characteristic features and progressions. Contributions to a new subfamilial classification. Opera Botanica Belgica, 1, 1-271.

Rocha, C. F. D., Bergallo, H. G., Alves, M. A. S., \& van Sluys, M. (2003). A biodiversidade nos grandes remanescentes florestais do Estado do Rio de Janeiro e nas restingas da Mata Atlântica. São Carlos: Rima Editora.

Rocha, C. F. D., Bergallo, H. G., Pombal Júnior, J. P., Geise, L., van Sluys, M., Fernandes, R., \& Caramaschi, U. (2004). Fauna de anfíbios, répteis e mamíferos do estado do Rio de Janeiro, Sudeste do Brasil. Publicações Avulsas do Museu Nacional, 104, 3-23.

Silva, J. M. C., \& Casteleti, C. H. M. (2005). Estado da biodiversidade da Mata Atlântica brasileira. In C. Galindo-Leal \& I. G. Câmara (Eds.), Mata Atlântica: biodiversidade, ameaças e perspectivas (pp. 43-59). São Paulo and Belo Horizonte: Fundação SOS Mata Atlântica Conservação Internacional.

Silva-Neto, S. J. \& Ávila, R. S. (2007). Uma nova espécie de Randia (Rubiaceae, Gardenieae) para o estado do Rio de Janeiro, Brasil. Rodriguésia, 58(4), 739-742.

Silva-Neto, S. J. \& Peixoto, A. L. (2012). Rubiaceae do Parque Nacional do Itatiaia, Rio de Janeiro, Brasil.
Boletim de Pesquisa do Parque Nacional do Itatiaia, 14, 1-169.

Siqueira-Filho, J. A., \& Leme, E. M. C. (2006). Fragmentos de Mata Atlântica do Nordeste: Biodiversidade, conservação e suas bromélias. Rio de Janeiro: Andrea Jackobsson Estúdio Editorial.

Souza, V. C., Mamede, M. C. H., Cordeiro, I., Prado, J., Barros, F., Wanderley, M. G. L., ... Rando, J. G. (2007). Critérios utilizados na elaboração da Lista Oficial de Espécies Ameaçadas de extinção no estado de São Paulo. In M. C. H. Mamede, V. C. Souza, J. Prado, F. Barros, M. G. L. Wanderley \& J. G. Rando (Eds.), Livro Vermelho das Espécies Vegetais Ameaçadas do Estado de São Paulo (pp. 15-20). São Paulo: Instituto de Botânica.

Stehmann, J. R., Forzza, R. C., Salino, A., Sobral, M., Costa, D. P., \& Kamino, L. H. Y. (2009). Plantas da Floresta Atlântica. Rio de Janeiro: Instituto de Pesquisas Jardim Botânico do Rio de Janeiro.

Thomas, W. W. (1999). Conservation and monographic research on the flora of Tropical America. Biodiversity and Conservation, 8, 1007-1015.

Vane-Wright, R. I., Humphries, C. J., \& Williams, P. H. (1991). Biological Conservation, 55, 235-254

Veloso, H. P., Rangel Filho, A. L. R., \& Lima. J. C. A. (1991). Classificação da vegetação brasileira, adaptada a um sistema universal. Rio de Janeiro: Instituto Brasileiro de Geografia e Estatística.

Zappi, D., Jardim, J., Souza, E. B., Di Maio, F. R., Barbosa, M. R., Valente, A. S. M., ... Monteiro, N. P. (2013). Rubiaceae. In G. Martinelli \& M. A. Moraes (Eds.), Livro Vermelho da Flora do Brasil (pp. 922-941). Rio de Janeiro: Instituto de Pesquisas Jardim Botânico do Rio de Janeiro. 
